\title{
Selected aspects of lifestyle of active boys in the older school age
}

\author{
Jana Kvintová, Martin Sigmund, \\ Michal Kudláček, Iva Dostálová
}

\begin{abstract}
The main objectives of this thesis was to identify and evaluate selected aspects of lifestyle (physical activity/inactivity, sedentary behaviour - watching TV and DVD, playing PC games, negative eating habits, substance abuse and sexual experience) in the research sample of 105 young boys from Olomouc, Prostějov and Přerov aged 11,13 and 15 years, with regularly controlled physical activity (ice hockey) and compare them with the same old boys from the HBSC study (The Health Behavior in School-aged Children). The results show that these young active boys have an overall healthier lifestyle than boys in the HBSC study. This pilot study can become the basis for other possible hypotheses and further research investigations.
\end{abstract}

Keywords: health, risk factors, school boys.

\section{Introduction}

What is being presented to the future teachers in terms of the Framework Education Programme is the fact that "Health is a state of complete physical, mental and social well-being. It is formed and influenced by many aspects such as lifestyle, healthilypreventive behaviour, quality of interpersonal relationships, quality of environment, safety of the man, etc." (VÚP, 2007, p. 72). According to the World Health Organization 
(WHO) the Health is defined as the state of complete physical, mental and social wellbeing and not merely the absence of disease or infirmity (WHO, 2003). Machová and Kubátová (2009) emphasize that health belongs to the most important values of every human. Physical activity (PA) has a huge impact on the human health and thus is denoted as a basic element of health and also one of the most significant needs of human being (Mitáš et al., 2013; Sigmund \& Sigmundová, 2011). Among the main determinants of health belong- genetic basis, medical care, environment and a lifestyle. (Bouchard, Blair, \& Haskell, 2007; Machová \& Kubátová, 2009; Dolanský 2008). These determinants of health have an impact on the human health either directly or indirectly, however they always influence one and other. Some of the determinants belong to the genetic makeup of the man (heredity, education) and some are adopted from the environment (nature, society). The influence of these factors may either protect ourselves and strengthen our health (biopositive) or the other way round, weaken it and become the cause of an illness or a health disorder (bionegative). Determinants of health can be divided into internal or external determinants. The internal determinants belong to the hereditary factors. Each human gains the genetic makeup of both parents at the beginning of the ontogenetic evolution. The aggregate of external factors and conditions are described as an external environment. The lifestyle, quality of life, working environment and medical services (its standard and quality of medical care) (Machová \& Kubátová, 2009).

The definition of Dolanský (2008), who presents the basic determinants influencing the human health in such proportion - lifestyle - personal behaviour: 50-60\%, genetic basis - genetic and constitutional factors: $10-15 \%$, socioeconomic environment - life environment: $20-25 \%$, medical care and services: $10-15 \%$, corresponds to the definition of the authors mentioned above.

The main factor influencing our health is definitely the lifestyle of a human. The term lifestyle is more and more discussed nowdays. Actually, it is one of the most important factors having the impact on the quality of our life. Its individual character varies from the way of life which has group character. Another contrast between the way of life and the lifestyle is different continuity between the factors influencing the lifestyle. For example, there can be mentioned things such as an individual development of the human, the impact of the surroundings, cultural level of man, family traditions and so on. The lifestyle is created during the lifetime and thus is variable at time because of the fact that the human needs change together with the time and alteration of an environment. According to Machová et al. $(2009,16)$ "the lifestyle includes forms of voluntary behaviour at specific situations that are based on an individual selection of various possibilities." In accordance with Slepičková (2005), the lifestyle can be characterized as a range of all human activities, beginning with thinking or behaviour up to the actions that are very significant in the human life and are typical, predictable and often repeated. Very often, the lifestyle is assessed according to the human opinions, 
attitudes and behaviour. Generally, the lifestyle is the manifestation of human personality. It includes forms of voluntary behaviour at specific situations that are based on an individual selection of various possibilities, where the selection depends on the age, temperament, education, economic situation, ethnicity, gender and value orientation of every human (Kubátová \& Kroufek, 2006).

The term lifestyle is often associated with the words like active, passive or inactive and sedentary. Generally, it is spoken about "the active lifestyle" or more precisely about the term "healthy lifestyle", which is more discussed in the society and is closely associated with the PA (Stejskal, 2004). "The active lifestyle" is the system of important activities, relationships and term related to it, practice focusing on achievement of the fully-fledged and harmonious relationship between the physical and mental side of the human (Valjent, 2008, 50). The healthier lifestyle is also a topic of one of the priorities of the WHO in the project Health 21(1999, 190) the aim 11 could be found: "People should adopt the healthier lifestyle by the year 2015". The outlook on better health and its quality which is related to the life health may help to motivate adults to the change of the unhealthy lifestyle and thus raise the quality of public health (van Oostrom et al., 2012). It is often mentioned that the lifestyle at childhood, maturing and the middle age is going to have an impact on the health at the old age. The healthy lifestyle is regarded as the most propitious factor influencing the overall health at the old age (Pluijm et al., 2007).

The presented study proceeds from the information mentioned above and with the statement of the WHO at the same time. The statement deals with the fact that behaviour and lifestyle at the adulthood are the results of the evolution during the childhood and maturing. In terms of the public health, the monitoring of behavioural components influencing health is very significant, especially among the young people. The young people with their specific risk factors (physical inactivity, sedentary behaviour, watching TV and DVD, playing PC games, negative eating habits, substance abuse etc.) should be the target group of preventive efforts in the area of health support.

The aim of this study is the evaluation of selected aspects of the lifestyle of boys at the age of 11, 13 and 15 years old with regular PA and the comparison of the aspects with data from HBSC survey (The Health Behavior in School-aged Children).

\section{Methods}

\section{Research sample}

The research sample consisted of 105 active boys at the age of $11(n=32), 13(n=34)$ and 15 ( $n=39$ ) living in Olomouc, Prostějov, and Přerov. For better understanding of our 
research sample, it is important to add that the group consisted of boys with regular, controlled and organized PA with the major focus on ice-hockey.

Data from HBSC study were used for comparison with our data. HBSC study is international research with collaborative character focusing on the lifestyle of children. This study monitors the occurrence of behavioural components influencing health among the children and adolescents. The main aim of HBSC study is to increase the knowledge about their lifestyle and help them understand it (Kalman et al., 2011).

\section{Data collection methods}

A data collection took place in the year 2013. The study has pilot character and was accomplished on specific file of active boys at older school age. During the research, the standardized questionnaire of an international study of Health Behaviour in Schoolaged Children (HBSC) was utilized. The administration of the questionnaire was based on voluntariness and was also provided by the agreement of a legal representative. It was also realized without the presence of a teacher or a coach. During the study there was always present educated administrator who was willing to help with filling in the questionnaire. The utilization of the questionnaire was accomplished with the agreement of the head director of HBSC study for the Czech Republic, Michal Kalman. A statistical processing of the results was realized with the help of the program, Statistica in 10.0. (Statistica, Tulsa, USA). Evaluation of the differences of relative figures of independent files was accomplished by pivot tables through Chi-square test. Level of statistical significance was tested on the grade of $p \leq 0.05 ; p \leq 0.01 ; p \leq 0.001$.

\section{Results}

With a regard to the huge amount of ascertained and analysed data, we present selected findings concerning the lifestyle of young boys at the age of 11,13 and 15 years old at the result part of the research. Presentation of the findings mentioned above was realized in the categories of physical activity and inactivity, selected eating habits, experiences with smoking and drinking alcohol and experience with sexual intercourse.

\section{Physical activity and inactivity}

The $95 \%$ of all asked active boys was engaged in PA, at least, one hour a day and 3 days a week. As it was expected, the results of our respondents were much higher than the results of boys of HBSC study. To be more specific the results were concerning the number of days in PA during a week among all age categories (Table 1). The most evi- 
dent difference of $44 \%$ could be seen among the 15 years old boys who are engaged in regular PA during all week.

Table 1

The comparison of regular physical activity during a week among active boys and boys from HBSC study at the age of 11,13 and 15 (\%)

\begin{tabular}{|c|c|c|c|c|c|c|c|c|c|}
\hline \multirow{2}{*}{$\begin{array}{c}\text { Active } \\
\text { days } \\
\text { in week }\end{array}$} & \multicolumn{3}{|c|}{11 years } & \multicolumn{3}{|c|}{13 years } & \multicolumn{3}{|c|}{15 years } \\
\hline & $\begin{array}{l}\text { Active } \\
\text { Boys }\end{array}$ & HBSC & $p$ & $\begin{array}{l}\text { Active } \\
\text { boys }\end{array}$ & HBSC & $p$ & $\begin{array}{c}\text { Active } \\
\text { boys }\end{array}$ & HBSC & $p$ \\
\hline$<1$ & 0 & 4 & ns & 0 & 3 & ns & 0 & 3 & ns \\
\hline 1 & 3 & 6 & ns & 6 & 7 & ns & 0 & 6 & * \\
\hline 2 & 3 & 11 & $*$ & 3 & 8 & ns & 0 & 10 & ** \\
\hline 3 & 6 & 13 & ns & 18 & 13 & ns & 10 & 15 & * \\
\hline 4 & 9 & 16 & ns & 12 & 15 & ns & 10 & 16 & * \\
\hline 5 & 9 & 13 & ns & 15 & 14 & ns & 5 & 15 & $*$ \\
\hline 6 & 28 & 9 & $* *$ & 12 & 11 & ns & 31 & 10 & *** \\
\hline 7 & 42 & 28 & ns & 35 & 30 & ns & 44 & 24 & ** \\
\hline
\end{tabular}

Legend: $p$ - statistical significance; ${ }^{*}-p \leq 0.05 ;{ }^{* *}-p \leq 0.01$; ns - non significant

The $45 \%$ of active respondents spends watching TV, video or DVD $2-3$ hours a day during working days. The $28 \%$ of respondents watch TV an hour a day. The active boys in comparison with the boys from HBSC study watch TV at shorter intervals, from 30 minutes a day to 1 hour a day. On the other hand, the boys from HBSC study spend by watching TV intervals in the range of 2-6 hours. (Table 2). Concerning the weekend the time spent by watching TV among the $43 \%$ of active boys is in the range of 2-3 hours whereas among the boys from HBSC study it is spoken about 40\% (Table 2) The increase of time spent in watching TV was recorded in the time range higher than 4 hours a day. The $23 \%$ of both active boys and those from HBSC study spends 4-5 hours a day by watching TV at weekend. The $12 \%$ of boys from HBSC study spends 6 hours by watching TV while the $4 \%$ of active boys watches TV for 6 hours. 
Table 2

The comparison of time spent on watching TV, DVD or video at working days between active boys and boys from HBSC study at the age of 11-15 (\%)

\begin{tabular}{|c|c|c|c|c|c|c|c|}
\hline \multirow{2}{*}{$\begin{array}{l}\text { Watching } \\
\text { TV, DVDs, video } \\
\text { at week uring } \\
\text { the day }\end{array}$} & \multicolumn{3}{|c|}{$11-15$ years } & \multirow{2}{*}{$\begin{array}{c}\text { Watching } \\
\text { TV, DVDs, } \\
\text { video at week } \\
\text { during the weekend }\end{array}$} & \multicolumn{3}{|c|}{$11-15$ years } \\
\hline & $\begin{array}{c}\text { Active } \\
\text { boys }\end{array}$ & HBSC & $p$ & & $\begin{array}{c}\text { Active } \\
\text { boys }\end{array}$ & HBSC & $p$ \\
\hline never & 5 & 4 & ns & never & 2 & 5 & ns \\
\hline $1 / 2$ hours & 15 & 9 & ns & $1 / 2$ hours & 7 & 7 & ns \\
\hline 1 hours & 28 & 21 & ns & 1 hours & 20 & 13 & ns \\
\hline $2-3$ hours & 45 & 47 & ns & $2-3$ hours & 43 & 40 & ns \\
\hline $4-5$ hours & 7 & 13 & ns & $4-5$ hours & 23 & 23 & ns \\
\hline$>6$ hours & 0 & 5 & $*$ & $>6$ hours & 4 & 12 & * \\
\hline
\end{tabular}

Legend: $p$ - statistical significance; ${ }^{*}-p \leq 0.05$; ns - non significant

Table 3 presents the proportional representation of respondents of all age categories at time units which are spent by playing games on the computer or on game console during working days and weekend. The biggest proportion of active boys is engaged in computer activities for 1 hour a day during working days whereas the $27 \%$ of boys from HBSC spends 2 hours a day at working days. In the same way, as it was with watching TV, the active boys spend shorter time intervals by playing computer games compare to boys from HBSC study. More than 4 hours a day are spent on playing computer games by the boys from HBSC study (23\%) which is more than time spent on the same activities by active boys (2\%).

The time spent on playing computer games is much higher during a weekend in terms of both, active boys and those from HBSC study. The active boys (23\%) play computer games often for 2 hours and the amount of time and respondents spent on that activities is getting higher. The $18 \%$ of active boys does computer activities for more than 4 hours. Also, the boys from HBSC study spend more time nearby the PC for more than 4 hours during the weekend (36\%). 
Table 3

The comparison of time spent on playing games on $P C$ or game console at working days among active boys and boys from HBSC study at the age of 11-15 (\%)

\begin{tabular}{|c|c|c|c|c|c|c|c|}
\hline \multirow{2}{*}{$\begin{array}{c}\text { Playing } \\
\text { PC games } \\
\text { at the week } \\
\text { during the day }\end{array}$} & \multicolumn{3}{|c|}{$11-15$ years } & \multirow{2}{*}{$\begin{array}{c}\text { Playing } \\
\text { PC games } \\
\text { at the week } \\
\text { during the weekend }\end{array}$} & \multicolumn{3}{|c|}{$11-15$ years } \\
\hline & $\begin{array}{l}\text { Active } \\
\text { boys }\end{array}$ & HBSC & $p$ & & $\begin{array}{l}\text { Active } \\
\text { Boys }\end{array}$ & HBSC & $p$ \\
\hline never & 12 & 12 & ns & never & 12 & 12 & ns \\
\hline $1 / 2$ hours & 13 & 11 & ns & $1 / 2$ hours & 14 & 8 & ns \\
\hline 1 hours & 32 & 19 & * & 1 hours & 19 & 14 & ns \\
\hline 2 hours & 27 & 21 & ns & 2 hours & 23 & 18 & ns \\
\hline 3 hours & 15 & 15 & ns & 3 hours & 15 & 12 & ns \\
\hline 4 hours & 1 & 8 & * & 4 hours & 9 & 10 & ns \\
\hline 5 hours & 0 & 6 & * & 5 hours & 4 & 8 & ns \\
\hline 6 hours & 0 & 3 & ns & 6 hours & 4 & 6 & ns \\
\hline$>7$ hours & 1 & 6 & ns & $>7$ hours & 1 & 12 & ** \\
\hline
\end{tabular}

Legend: $p$ - statistical significance; ${ }^{*}-p \leq 0.05 ;{ }^{* *}-p \leq 0.01$; ns - non significant

\section{Selected eating habits}

There is higher proportion of active boys who have breakfast regularly in comparison with boys from HBSC study of the same age (Table 4). Concerning the working days, the lower number of active boys goes to school without having a breakfast (0-15\% depending on the age) in comparison with boys from HBSC study (15-23\% depending on the age). In terms of the snacks at school, the most of respondents, including both active boys and those from HBSC study has a snack at school (90-95\%).

The highest proportion of active boys having a lunch at school is among those at the age of $13(88 \%)$, then 15 years old (87\%) and the lowest proportion belongs to the active boys at the age of 11 years old (78\%). There are more active boys having lunch at school (except for those at the age of 11 years old where the number is the same in both groups) in comparison with boys from HBSC study. The most evident difference is among boys from HBSC at the age of 15 where only $66 \%$ has a lunch (Table 5). The afternoon snack belongs among the most skipped meal at school by boys in comparison with a lunch or snack. On the average $75 \%$ of active boys of all age categories has a snack as a part of daily diet whereas among the boys of all age categories from HBSC the proportion is only $62 \%$. The highest proportion of boys who have a snack in the afternoon belongs to the group of boys at the age of $15(82 \%)$ while just $88 \%$ of boys from HBSC do the same (66\%). 
Table 4

The comparison of the number of working days when boys have a breakfast during a week between active boys and boys from HBSC study at the age of 11, 13 and 15 (\%)

\begin{tabular}{|c|c|c|c|c|c|c|c|c|c|}
\hline $\begin{array}{c}\text { Active } \\
\text { days } \\
\text { in week }\end{array}$ & \multicolumn{3}{|c|}{11 years } & \multicolumn{3}{c|}{13 years } & \multicolumn{3}{c|}{15 years } \\
\cline { 2 - 10 } & $\begin{array}{c}\text { Active } \\
\text { Boys }\end{array}$ & HBSC & $p$ & $\begin{array}{c}\text { Active } \\
\text { boys }\end{array}$ & HBSC & $p$ & $\begin{array}{c}\text { Active } \\
\text { boys }\end{array}$ & HBSC & $p$ \\
\hline 0 & 0 & 15 & ns & 15 & 23 & & 0 & 23 & $* *$ \\
\hline 1 & 0 & 3 & ns & 0 & 4 & & 5 & 4 & ns \\
\hline 2 & 3 & 4 & ns & 6 & 5 & & 5 & 5 & ns \\
\hline 3 & 3 & 5 & ns & 3 & 6 & & 8 & 6 & ns \\
\hline 4 & 13 & 5 & ns & 9 & 5 & & 3 & 5 & ns \\
\hline 5 & 81 & 69 & ns & 68 & 58 & & 77 & 58 & $* *$ \\
\hline
\end{tabular}

Legend: $p$ - statistical significance; ${ }^{* *}-p \leq 0.01 ;$ ns - non significant

Table 5

The comparison of eating habits between active boys and boys from HBSC study at the age of 11,13 and 15 (\%)

\begin{tabular}{|c|c|c|c|c|c|c|c|c|c|}
\hline \multirow{2}{*}{ Eating habits } & \multicolumn{3}{|c|}{11 years } & \multicolumn{3}{c|}{13 years } & \multicolumn{3}{c|}{15 years } \\
\cline { 2 - 10 } & $\begin{array}{c}\text { Active } \\
\text { boys }\end{array}$ & HBSC & $p$ & $\begin{array}{c}\text { Active } \\
\text { boys }\end{array}$ & HBSC & $p$ & $\begin{array}{c}\text { Active } \\
\text { boys }\end{array}$ & HBSC & $p$ \\
\hline Snack at school & 100 & 95 & $*$ & 100 & 90 & $* *$ & 97 & 90 & $*$ \\
\hline Lunch at school & 78 & 78 & ns & 88 & 76 & $*$ & 87 & 66 & $* *$ \\
\hline Afternoon snack & 75 & 60 & $*$ & 68 & 62 & Ns & 82 & 66 & $* *$ \\
\hline
\end{tabular}

Legend: $p$ - statistical significance; ${ }^{*}-p \leq 0.05 ;{ }^{* *}-p \leq 0.01$; ns - non significant

\section{The consumption of fruit, vegetables and sweets}

The consumption of fruit, vegetables and sweets were another part of this study. More than half of the monitored boys (active boys and those from HBSC) eat fruit at least once a week. The $44 \%$ of active boys at the age of $11,33 \%$ of boys at the age of 13 and $16 \%$ of boys at the age of 15 eat fruit once or more times a day (Table 6). Regarding the HBSC study, there is a lower representation of boys consuming fruit regularly. The proportion of boys who eat fruit once or more times a day is about $23 \%$ among boys at the age of 11 and $28 \%$ of boys at the age of 13 . The most evident difference is only in the case of boys from HBSC study at the age of 15 who consume fruit more times (30\%) than the active boys (16\%) (Table 6).The boys from HBSC study eat vegetables 
once or more times a day while the active boys consume vegetables in lower proportion. Concerning the HBSC the proportion of consumption of vegetables is about $30 \%$ of boys at the age of $11,27 \%$ of boys at the age of 13 and $21 \%$ of boys at the age of 15 (Table 7). In terms of the active boys, $15 \%$ of boys at the age of $11,18 \%$ of boys at the age of 13 and $16 \%$ of boys at the age of 15 consume vegetables regularly. The biggest representation of consumption of vegetables is at least once a week among both, the active boys and boys from HBSC.

Table 6

The comparison of consumption of fruit between active boys and boys from HBSC study at the age of 11,13 and 15 (\%)

\begin{tabular}{|c|c|c|c|c|c|c|c|c|c|}
\hline \multirow{2}{*}{$\begin{array}{c}\text { Consumption } \\
\text { of fruit }\end{array}$} & \multicolumn{3}{|c|}{11 years } & \multicolumn{3}{c|}{13 years } & \multicolumn{3}{c|}{15 years } \\
\cline { 2 - 11 } & $\begin{array}{c}\text { Active } \\
\text { boys }\end{array}$ & HBSC & $p$ & $\begin{array}{c}\text { Active } \\
\text { boys }\end{array}$ & HBSC & $p$ & $\begin{array}{c}\text { Active } \\
\text { boys }\end{array}$ & HBSC & $p$ \\
\hline Never & 3 & 4 & $\mathrm{~ns}$ & 0 & 2 & $\mathrm{~ns}$ & 0 & 1 & $\mathrm{~ns}$ \\
\hline Rarely & 3 & 14 & $* *$ & 3 & 8 & $\mathrm{~ns}$ & 0 & 8 & $* *$ \\
\hline once of week & 50 & 60 & $\mathrm{~ns}$ & 64 & 63 & $\mathrm{~ns}$ & 84 & 62 & $* *$ \\
\hline every day & 25 & 15 & $\mathrm{~ns}$ & 21 & 19 & $\mathrm{~ns}$ & 8 & 22 & $* *$ \\
\hline > every day & 19 & 8 & $*$ & 12 & 9 & $\mathrm{~ns}$ & 8 & 8 & $\mathrm{~ns}$ \\
\hline
\end{tabular}

Legend: $p$ - statistical significance; ${ }^{*}-p \leq 0.05 ;{ }^{* *}-p \leq 0.01$; ns - non significant

Table 7

The comparison of consumption of vegetables between active boys and boys from HBSC study at the age of 11,13 and 15 (\%)

\begin{tabular}{|c|c|c|c|c|c|c|c|c|c|}
\hline \multirow{2}{*}{$\begin{array}{c}\text { Consumption } \\
\text { of vegetables }\end{array}$} & \multicolumn{3}{|c|}{11 years } & \multicolumn{3}{c|}{13 years } & \multicolumn{3}{c|}{15 years } \\
\cline { 2 - 11 } & $\begin{array}{c}\text { Active } \\
\text { boys }\end{array}$ & HBSC & $p$ & $\begin{array}{c}\text { Active } \\
\text { boys }\end{array}$ & HBSC & $p$ & $\begin{array}{c}\text { Active } \\
\text { boys }\end{array}$ & HBSC & $p$ \\
\hline Never & 9 & 5 & ns & 0 & 5 & $*$ & 3 & 3 & ns \\
\hline Rarely & 0 & 7 & $\mathrm{~ns}$ & 0 & 7 & $* *$ & 5 & 7 & $\mathrm{~ns}$ \\
\hline once of week & 69 & 58 & $\mathrm{~ns}$ & 82 & 61 & $* *$ & 76 & 69 & $\mathrm{~ns}$ \\
\hline every day & 6 & 21 & $* *$ & 15 & 17 & $\mathrm{~ns}$ & 8 & 16 & $\mathrm{~ns}$ \\
\hline > every day & 13 & 9 & $\mathrm{~ns}$ & 3 & 10 & $*$ & 8 & 5 & $\mathrm{~ns}$ \\
\hline
\end{tabular}

Legend: $p$ - statistical significance; ${ }^{*}-p \leq 0.05 ;{ }^{* *}-p \leq 0.01$; ns - non significant

The most of the respondents consume sweets at least once a week. Concerning the active boys, the proportion is ranged between $61-72 \%$, depending on the age. Regarding boys from HBSC, the proportion ranged from 60 to63\%, depends on the age (Table 8 ). 
In terms of the daily consumption of sweets (at least once or more times a day), the $12 \%$ of active boys at the age of $11,33 \%$ of boys at the age of 13 and $26 \%$ of boys at the age of 15 consumes such amount. On the other hand, the $23 \%$ of boys from HBSC study at the age of $11,28 \%$ of boys at the age of 13 and $30 \%$ of boys at the age of 15 consumes such amount.

\section{Table 8}

The comparison of consumption of sweets between active boys and boys from HBSC study at the age of 11,13 and 15 (\%)

\begin{tabular}{|c|c|c|c|c|c|c|c|c|c|}
\hline \multirow{2}{*}{$\begin{array}{c}\text { Consumption } \\
\text { of sweets }\end{array}$} & \multicolumn{3}{|c|}{11 years } & \multicolumn{3}{c|}{13 years } & \multicolumn{3}{c|}{15 years } \\
\cline { 2 - 11 } & $\begin{array}{c}\text { Active } \\
\text { boys }\end{array}$ & HBSC & $p$ & $\begin{array}{c}\text { Active } \\
\text { boys }\end{array}$ & HBSC & $p$ & $\begin{array}{c}\text { Active } \\
\text { boys }\end{array}$ & HBSC & $p$ \\
\hline Never & 0 & 4 & $\mathrm{~ns}$ & 0 & 2 & $\mathrm{~ns}$ & 0 & 1 & $\mathrm{~ns}$ \\
\hline Rarely & 16 & 14 & $\mathrm{~ns}$ & 3 & 8 & $\mathrm{~ns}$ & 13 & 8 & $\mathrm{~ns}$ \\
\hline once of week & 72 & 60 & $\mathrm{~ns}$ & 64 & 63 & $\mathrm{~ns}$ & 61 & 62 & $\mathrm{~ns}$ \\
\hline every day & 6 & 15 & $*$ & 24 & 19 & $\mathrm{~ns}$ & 26 & 22 & $\mathrm{~ns}$ \\
\hline >every day & 6 & 8 & $\mathrm{~ns}$ & 9 & 9 & $\mathrm{~ns}$ & 0 & 8 & $* *$ \\
\hline
\end{tabular}

Legend: $p$ - statistical significance; ${ }^{*}-p \leq 0.05 ;{ }^{* *}-p \leq 0.01$; ns - non significant

\section{Experiences with smoking tobacco, drinking alcohol and sexual intercourse}

Concerning the smoking tobacco, there is a strong imbalance between active boys and boys from HBSC study. The results of boys from HBSC are manifoldly higher at all age categories than those of active boys. In other words, there is $76-94 \%$ of active boys without any experience with smoking. On the other hand, a number of boys from HBSC without any experience with smoking is ranged between $30-75 \%$, depends on the age. However, the differences concerning a drunkenness at least twice per life between active boys and those from HBSC study is are much more evident.In terms of the experiences with drunkenness among active boys, the $3 \%$ of boys at the age of 13 has such experience, $8 \%$ of boys at the age of 15 experienced drunkenness and boys at the age of 11 have no experience with it. On the contrary, $5 \%$ of boys from HBSC at the age of 11 confirmed drunkenness, $17 \%$ of boys at the age of 13 experienced it as well and the highest proportion of experience with drunkenness is in $47 \%$ of boys at the age of 15 .

Regarding the experiences with sexual intercourse, that type of question was laid just to the boys at the age of 15 . It was discovered that that kind of experience had $19 \%$ of active boys. The $24 \%$ of respondents abstained in the question. There is a mildly 
higher proportion of the experience with sexual intercourse among boys from HBSC study, however, the difference is not so significant in that case (Table 9).

Table 9. The comparison of experiences with smoking tobacco, drunkenness and sexual intercourse between active boys and boys from HBSC study at the age of 11, 13 and 15 (\%).

\begin{tabular}{|c|c|c|c|c|c|c|c|c|c|}
\hline \multirow{2}{*}{$\begin{array}{c}\text { Addictive } \\
\text { substances }\end{array}$} & \multicolumn{3}{|c|}{11 years } & \multicolumn{3}{c|}{13 years } & \multicolumn{3}{c|}{15 years } \\
\cline { 2 - 10 } & $\begin{array}{c}\text { Active } \\
\text { boys }\end{array}$ & HBSC & $p$ & $\begin{array}{c}\text { Active } \\
\text { boys }\end{array}$ & HBSC & $p$ & $\begin{array}{c}\text { Active } \\
\text { Boys }\end{array}$ & HBSC & $p$ \\
\hline Smoking & 6 & 25 & $* * *$ & 24 & 50 & $* * *$ & 18 & 70 & $* * *$ \\
\hline Alcohol intoxication & 0 & 5 & $*$ & 3 & 17 & $* *$ & 8 & 47 & $* * *$ \\
\hline Sexual intercourse & & & & & & & 19 & 22 & ns \\
\hline
\end{tabular}

Legend: $p$-statistical significance; ${ }^{*}-p \leq 0.05 ;{ }^{* *}-p \leq 0.01 ;{ }^{* * *}-p \leq 0.001$; ns-non significant

\section{Discussion}

The research dealing with a growth and evolution of children is focused on an evaluation of lifestyle, especially on the growing prevalence of overweight and obesity among young population (Bunc, 2008). The presented facts have been monitored not only at the domestic circumstances, but it has been discussed all around the world ( $\mathrm{Ng}$ et al., 2014). Important factors influencing health, growth and evolution of young organism and overall lifestyle in the holistic context are related to things like PA, nutrition, reduction of stress and its control, the issue of drug addiction, elimination of social pathological phenomenon and also the period of the start of a sexual life of a young human. Above mentioned factors could be considered as significant factors having an impact on the health of a human. In the context of the issue mentioned above and findings, we discuss the topic further.

The adequate PA and healthy eating habits are considered to be significant factors influencing the regulation of body weight (Kirschenbaum \& Gierut, 2013). It was found that children who are engaged in a physical activity, at least, an hour a day have healthier eating habits than the inactive children. The active children have also breakfast more often than the inactive children and their consumption of fruit and vegetable is much higher (Morin, Tursotte, \& Perreault, 2013). According to Machová and Kubátová, et al. (2009) the daily consumption of fruit and vegetable should reach the value about $600 \mathrm{~g}$ in a ratio of 5:3 in favour for vegetable. Based on the Tables 6 and 7, it is evident that $31 \%$ of active boys consume fruit, and $17 \%$ of them vegetable on a daily basis. According to boys with regular physical activity, the most frequent consumption of fruit and vegetables was reported only once a week. The higher the age, the higher is the daily 
consumption of sweets. Just $8 \%$ of monitored active boys at the age of 11 consumed sweets every day. In the case of active boys at the age of 13 the proportion is $24 \%$ and the highest proportion has boys at the age of 15 . The ascertained findings among Czech boys are similar to the research carried out among children in Slovakia. According to Babinská, Vituriášová and Rosinký (2007), the highest the age, the higher the proportion of children having fast food or sweets regularly is. What has been monitored is the increase from $3 \%$ of children at the age of $6-8$ to $25 \%$ of children at the age of $15-26$.

The eating habits are adopted from our own environment, often from our parents. If a child sees his parents having breakfast since his early childhood there is a big chance that these habits will be used in the future. The three-quarters of active boys have breakfast every day during working days. Only $15 \%$ of surveyed active boys at the age of 13 do not have a breakfast at all on working days. Concerning the HBSC study, the higher the age of children was, the lower the number of children having breakfast became. There was the most evident decrease among the active boys having breakfast from the age 11 to 13 in the research sample. In comparison with boys from HBSC study, there is higher proportion of active boys having breakfast in all age categories. Concerning the weekends, the breakfast of active boys is more regular, which can be result of the parent's supervision. The best results have been discovered in the morning snacks. All active boys at the age of 11 and 13 have a snack at school regularly. In terms of all monitored boys at the age of 15 , the proportion was $97 \%$. Despite of the fact that the proportion of active boys having snack regularly is evidently higher, we can say that the number of boys from HBSC study having snack regularly is satisfying (90-95\%, depending on the age).

Active boys have lunch at the average of $84 \%$. In the comparison with boys from HBSC study who have lunch at the average of $73 \%$, the difference is statistically significant. Just $34 \%$ of children at the age of 11, 13 and 15 in Scotland has lunch at school (Kirby \& Currie, 2010).

Regarding the afternoon snack, the proportion among active boys is $75 \%$ and concerning the boys from HBSC study, the proportion is getting lower (63\%).

The World Health Organization published a recommendation in relationship to PA in the year 2010. Children at the age of 5 to 17 should spend at least 60 min on PA a day. The aerobic activity is generally preferred (WHO, 2010). With respect to the health of the young organism, it is important that the principle of optimal development and adequacy of PA should determine the controlled PA and exercise of young organism. The capacity of daily physical performance on the level of 12-14 thousand steps on middle intensity exercise with the duration of $90 \mathrm{~min}$, focusing on versatile physical development is recommended for a healthy growth and evolution of boys at the age of $6-11$. Concerning the boys at the age of $12-18$, the capacity of daily physical activity performance on the level of 11-13 thousand steps with middle intensity and the duration of $60 \mathrm{~min}$ or the performance of the high intensity with the duration of $20 \mathrm{~min}$ 
3 times a week is recommended (Kudláček \& Frömel, 2012; World Health Organization, 2010). A specialized sports preparation among children and youth should not be realized in the higher extent until they reach the period of pubescence. That kind of sports preparation is bio-psycho-social acceptable only if the versatile physical development is preserved (Šafár̆, 2012).

Regarding physical, mental and social development, the quality of PA and the way of spending free time in the life of young people play an important role (Currie et al., 2012). According to the research HBSC from the year 2010, three-quarters of Czech children do not fulfil the recommendations published by WHO. There is a growth of PA among boys from HBSC study at the age of $11-13$. At the age of 15 , physical activity has a tendency to decline back to the level at the age of 11 . In terms of the active boys, there is a decline in PA at the age of 13. Physical activity tends to rise at the age of 15 to the level of children at the age of 11 .

In the context of the enormous development of modern information technologies, the sedentary behaviour as the significant phenomenon important for the human health has emerged (Hallal et al., 2012). This phenomenon has gradually become a part of regulations and international recommendations, which states that acceptable daily time spent on watching TV should not exceed 2 hours (American Academy of Pediatrics, Committee on Public Education, 2001). Excessive watching of TV among children is also connected with an increased consumption of sweet drinks, fat meals and a lower consumption of fruit and vegetables. The relation between the excessive TV watching among children and a higher consumption of sweet drinks, fat meals and a lower consumption of fruit and vegetables were found (Currie et al., 2008).

In a comparison of active boys and boys from HBSC study, apparent differences could be seen, especially in the category of playing computer games longer than four hours. To be more specific, it is spoken of the difference between $23 \%$ of boys from HBSC study and $2 \%$ of active boys. The time spent on playing computer games is increasing at weekends ( $18 \%$ of active boys and $36 \%$ of boys from HBSC play PC games more than four hours). According to the official information (2008), the 5.4 mil. of people dies as consequences of smoking tobacco. The most frequent causes of death, in that case, are cardiovascular diseases and malignant tumors. About $90 \%$ of smoker has started to smoke before the age of 18 (Ellickson, McGuigan, \& Klein, 2001). In terms of the smoking in Europe, the $21 \%$ of boys and $17 \%$ of girls at the age of $13-15$ smokes at least once a month (Warren et al., 2008). Regarding our research, evident differences have been found between experience with smoking among active boys and boys from HBSC. The most evident difference could be seen among boys at the age of 15 , where $18 \%$ of active boys versus $70 \%$ of boys from HBSC study confessed such experience (Table 9). In comparison with Czech youth, the Slovakian youth has worse results, concerning the smoking experience at all age groups. The occurrence of smoking experience is higher in Slovakia (relatively, about 20-30\%), where girls smoke more than boys (Kalman, et al., 2011). 
Regarding the alcohol or drunkenness twice a life, the active boys have less experience with it than boys from HBSC study. The most evident difference could be seen among boys at the age of 15 , where $8 \%$ of active boys versus $47 \%$ of boys from HBSC study confessed such experience. The last question from the questionnaire was connected with experience with sexual intercourse. Almost one-quarter of respondents rejected to answer. In the conclusion, it could be said that there has not been found the evident difference among monitored groups of respondents. According to Metzler et al. (1994), the sexual debut is influenced by contact with people of the same age being characterized by problematic behaviour, low control by parents and stressed relationships within a family.

\section{Conclusion}

The results show that these physically active school boys (young ice hockey players) spend more time being physically active and have an overall healthier lifestyle than boys in the HBSC study.

The conclusions of that pilot study are based on main findings:

- Young active boys spend more time on physical activities during a whole week and also spend less time by watching TV or playing computer games than the boys from HBSC study.

- Active boys spend often 2-3 hours a day on watching TV or playing on PC.

- The time spent on watching monitors is longer at weekends in comparison with working days among all boys.

- Active boys have a breakfast more times during working days or weekends than the boys from HBSC study at the same age.

- The most of the active boys have a morning snack at school (99\%).

- Active boys have a lunch at school more times than boys from HBSC study.

- The $31 \%$ of fruit and $18 \%$ of vegetable is consumed by active boys every day.

- The higher is the age of all boys the higher is the daily consumption of sweets.

- The experience with smoking tobacco is evidently lower among the active boys (16\%) in comparison with boys from HBSC study (48\%).

- Experience with drunkenness among the boys at the age of 15 is evidently lower among active boys (8\%) in comparison with boys from HBSC study (47\%).

- Experience with sexual intercourse was confessed by $19 \%$ of active boys at the age of 15 and $22 \%$ of boys from HBSC study, however, the difference is not so evident.

The presented results and conclusion of the specific group of active boys (players of ice hockey) in comparison with boys from HBSC study, gained through that pilot research are able to create working hypothesis and conditions for further researches. It 
is also possible to implement presented findings to pedagogical training and other work with a youth.

\section{Acknowledgements}

The study is dedicated to the following projects. Internal grant of PDF UP: Psychosocial determinants of health among subjects in educational environment and IGA_PdF_2016_020 Selected psychosocial factors affecting the health of current University students of teaching.

\section{References}

American Academy of Pediatrics. Committee on Public Education. (2001). Children, adolescents, and television. Pediatrics, 107(2), 423-426. doi: 10.1542/peds.107.2.423.

Babinská, K., Vitáriušová, E., \& Rosinský, J. (2007). Stravovací režim školákov na Slovensku. Pediatria pre praxi, 7(4), 218-220.

Bouchard, C., Blair, S. N., \& Haskell, W. L. (2007). Physical activity and health. Champaign, IL: Human Kinetics.

Bunc, V. (2008). Nadváha a obezita dětí - životní styl jako příčina a důsledek [Overweight and obesity in children - life style as a cause and consequence]. Česká kinantropologie, 12(3), 61-69.

Currie, C., Zanotti, C., Morgan, A., Currie, D., de Looze, M., Roberts, C. et al. (Eds.). (2012). Social determinants of health and well-being among young people. Health Behaviour in School-aged Children (HBSC) study: International report from the 2009/2010 survey. Copenhagen: WHO Regional Office for Europe.

Dolanský, H. (2008). Veřejné zdravotnictví. Opava: Slezská univerzita v Opavě.

Ellickson, P. L., McGuigan, K. A., \& Klein, D. J. (2001). Predictors of late-onset smoking and cessation over 10 years. Journal of Adolescent Health, 29(2), 101-108.

Hallal, P. C., Andersen, L. B., Bull, F. C., Guthold, R., Haskell, W., \& Ekelund, U. (2012). Global physical activity levels: Surveillance progress, pitfalls, and prospects. The Lancet, 380(9838), 247-257.

Kalman, M., Sigmund, E., Sigmundová, D., Hamřík, Z., Beneš, L., Benešová, D., Csémy, L., \& HBSC český národní tým. (2011). Národní zpráva o zdraví a životním stylu dětí a školákủ. Olomouc: Univerzita Palackého v Olomouci.

Kirby, J., \& Currie, C. (2010). Nutrition and Health among young people in Scotland. HBSC Briefing, 17.

Kirschenbaum, D. S., \& Gierut, K. J. (2013). Five recent expert recommendations on the treatment of childhood and adolescent obesity: toward an emerging consensus - a stepped care approach. Childhood Obesity, 9(5), 376-385.

Křivohlavý, J. (2001). Psychologie zdraví. Praha: Portál.

Kubátová, D., \& Kroufek, R. (2006). Člověk, zdraví a țivotní prostředí. Ústí nad Labem: MINO.

Kudláček, M., \& Frömel, K. (2012). Sportovní preference a pohybová aktivita studentek a studentů středních škol. Aktivní či inaktivní životní styl středoškoláků? Univerzita Palackého: Olomouc.

Machová, J., \& Kubátová, D. et al. (2009). Výchova ke zdraví. Praha: Grada.

Metzler, C. W., Noell, J., Biglan, A., Ary, D., \& Smolkowski, K. (1994). The social-context for risky sexualbehavior among adolescents. Journal of Behavioral Medicine, 17(4), 419-438. 
Mitáš, J., Frömel, K., Vašíčková, J., Dygrýn, J., \& Pelclová, J. (2013). Mezinárodní přístupy ve výzkumu pohybově aktivního životního stylu v environmentálním kontextu. In M. Kopecký, K. Kikalová, \& J. Tomanová (Eds.), Antropologicko-psychologicko-sociální aspekty podpory zdraví a výchovy ke zdraví (pp. 293-309). Olomouc: Pedagogická Fakulta, Univerzita Palackého.

Morin, P., Turcotte, S., \& Perreault, G. (2013). Relationship between eating behaviors and physical activity among primary and secondary school students: results of a cross-sectional study. The Journal of School Health, 83(9), 597-604.

Ng, M., Fleming, T., Robinson, M., Thomson, B., Graetz, N., Margono, C., ... Gakidou, E. (2014). Global, regional, and national prevalence of overweight and obesity in children and adults during 1980-2013: a systematic analysis for the Global Burden of Disease Study 2013. The Lancet, 6736(14), 1-16.

Pluijm, S. M. F., Visser, M., Puts, M. T. E., Dik, M. G., Schalk, B. W. M., Van Schoor, N. M., Schaap, L. A., Deeg, D. J. H., \& Bosscher, R. J. (2007). Unhealthy lifestyles during the life course: association with physical decline in late life. Aging Clinical and Experimental Research, 19(1), 75-83.

Sigmund, E., \& Sigmundová, D. (2011). Pohybová aktivita pro podporu zdraví dětí a mládeže [Physical activity for the promotion of health of children and youth]. Olomouc: Univerzita Palackého.

Slepičková, I. (2005). Sport a volný čas vybrané kapitoly. Praha: Univerzita Karlova v Praze, Karolinum.

Šafář, M. (2012). Bio-psycho-sociální rizika vrcholového sportu dětí a mládeže. Pediatrie pro praxi, 13(6): 401-403.

Valjent, Z. (2008). Pokus o vymezení pojmu Aktivní životní styl. Česká kinantropologie, 12(2), 42-50.

Van Oostrom, S. H., Smit, H. A., Wendel-Vos, G. C., Visser, M., Verschuren, W. M., \& Picavet, H. S. (2012). Adopting an Active Lifestyle During Adulthood and Health-Related Quality of Life: The Doetinchem Cohort Study. American Journal of Public Health, 110(11), 62-68.

Výzkumný ústav pedagogický (2007). Rámcový vzdělávací program pro základní vzdělávání. Praha: Výzkumný ústav pedagogický, Retrieved on 9. 1. 2014 from the World Wide Web: http://www. vuppraha.cz/wp-content/uploads/2009/12/RVPZV_2007-07.pdf

WHO. (2003). WHO definition of Health. Retrieved on 4. 12. 2013 from the World Wide Web: http:// www.who.int/about/definition/en/print.html

WHO (2008). Report on the Global Tobacco Epidemic, 2008: The MPOWER package.

\section{Contact:}

PhDr. Jana Kvintová, Ph.D.

Department of Psychology and Pathopsychology

Faculty of Education, Palacký University in Olomouc

Žižkovo nám. 5, 77140 Olomouc, Czech Republic

E-mail: jana.kvintova@upol.cz

PhDr.Dr. Martin Sigmund, Ph.D.

Mgr. Michal Kudláček, Ph.D.

RNDr. Iva Dostálová, Ph.D.

Faculty of Physical Culture, Palacký University in Olomouc

třída Míru 117, 77111 Olomouc, Czech Republic

E-mail: martin.sigmund@upol.cz; michal.kudlacek@upol.cz; iva.dostalova@upol.cz 